\title{
Motivators of SME initial export choice and the European Union regional effect in manufacturing
}

Article

Accepted Version

Stouraitis, V., Harun, M. H. M. and Kyritsis, M. (2017) Motivators of SME initial export choice and the European Union regional effect in manufacturing. International Journal of Entrepreneurial Behavior \& Research, 23 (1). pp. 35-55. ISSN 1355-2554 doi: https://doi.org/10.1108//JEBR-05-2015-0120 Available at https://centaur.reading.ac.uk/81562/

It is advisable to refer to the publisher's version if you intend to cite from the work. See Guidance on citing.

Published version at: https://www.emeraldinsight.com/doi/full/10.1108/IJEBR-05-2015-0120

To link to this article DOI: http://dx.doi.org/10.1108/IJEBR-05-2015-0120

Publisher: Emerald

All outputs in CentAUR are protected by Intellectual Property Rights law, including copyright law. Copyright and IPR is retained by the creators or other copyright holders. Terms and conditions for use of this material are defined in the End User Agreement.

www.reading.ac.uk/centaur 
Central Archive at the University of Reading

Reading's research outputs online 


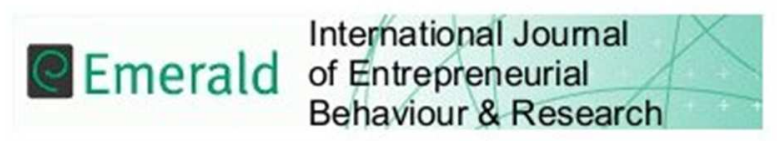

\section{Motivators of SME initial export choice and the European Union regional effect in manufacturing}

\begin{tabular}{|r|l|}
\hline Journal: & International Journal of Entrepreneurial Behavior \& Research \\
\hline Manuscript ID & IJEBR-05-2015-0120.R3 \\
\hline Manuscript Type: & Research Paper \\
\hline Keywords: & $\begin{array}{l}\text { Export, Manufacturing, Resource-based theory, Small to medium sized } \\
\text { Enterprises, Motivation, United Kingdom }\end{array}$ \\
\hline \multicolumn{2}{|l}{} \\
\hline
\end{tabular}

SCHOLARONE ${ }^{\prime \prime}$

Manuscripts 
Motivators of SME export initiation choice and the European Union regional effect in manufacturing

International Journal of Entrepreneurship Behavior and Research 


\begin{abstract}
Purpose - A global reach in exporting has been linked to profitability. The paper seeks to answer the influence of EU regulations on exporting decisions of UK manufacturing SMEs by investigating the home and host country based motivators behind SMEs' choice to export, and export regionally, within the EU.
\end{abstract}

Design/methodology/approach - Contrasting the Uppsala and Resource-based view perspectives (using a sample of UK independent manufacturing SMEs and utilizing a survey, correlation analysis and factor analysis), the paper finds and describes the effect of the most recurrent motivators from the literature on the SMEs' decision to export within the EU or not. Findings - The paper finds that SMEs whose latest international market entry was not in the EU scored significantly higher in the factor scorings for the motivators in the external dimension than participants whose latest entry was in the EU. Several motivators show an association with the choice to export per se. The importance of regionalization to export initiation (and EU membership) within the EU is emphasized in the results.

Practical implications - In the current climate, how can SMEs reduce market research costs for managers by relying solely and proactively on home country and internal advantages and motivators and being more aware of their surroundings? Managers and policymakers can direct their strategy, resources and policy more efficiently according to motivators; internal home country motivators (e.g. strengths of prices of products) direct the SME to overcome inter-regional liability of foreignness while host country motivators (e.g. legal restrictions in the host country) direct them to regional ventures.

Originality/value - The literature and empirical work on the topic has been fragmented and conflicting focusing on specific motivators but not necessarily justifying the selection or origin of motivators even less on SMEs or taking into account regionalization. The topic of EU membership effect on UK SMEs has been under researched.

Keywords - Small to medium-sized enterprises, resource-based theory, export, motivation, United Kingdom, manufacturing.

Paper Type - Research paper 


\section{Introduction}

The factors that set off SME growth (including exporting) are still in need of research (Bamiatzi and Kirchmaier, 2014). In international business research, the general consensus is that there is a positive relationship between international involvement of small and mediumsized firms (SMEs) and firm performance (Hilmersson, 2014). Edmunds and Khoury (1986) present the importance of exporting for SME profitability stating all SMEs should export. However, up until today the entry mode and pre-export phase research conducted on large multinationals is still much larger than on SMEs (Chellilah et al., 2010; Hilmersson, 2014). Much of the literature on the internationalization of SMEs involves a contrast between the process or stages approach (i.e. incremental learning), originated by Johanson and Vahlne (1977; 1990), and the international new ventures or 'born global' approach (Knight and Cavusgil, 2004; Oviatt and McDougall, 1994). Yet, as Fillis (2001) states the majority of frameworks fail to readily explain smaller firm internationalization behaviour and motivations. Research on geographical proximity for SME exporting has not focused on the inter-regional liability of foreignness between the European Union (EU) and its motivations, while it has been shown that SME internationalization performance is affected by geographical scope (D’Angelo et al., 2013; Rugman, 2003).

Work on the origin of the behavioural triggers of exporting (including location) is not as widespread as the work on the definition of the motivators per se (Tan et al., 2014). In addition the absence of any unifying theory for SME growth means that the literature continues to feature varied and fragmented growth measures explaining SME growth and exporting (Dobbs and Hamilton, 2007). Furthermore, previous research on regionalization and exporting has focused predominantly on the regional nature of large multinationals, as opposed to SMEs, while traditionally international trade in goods (and services) has been regarded as the principal channel for economic integration (Beleska-Spasova and Glaister, 2009; Cerrato and Piva, 2015). Behavioural triggers, or motivators, initiate the learning process by alerting the decision-maker to possible opportunities that are presented to the firm through an international venture. Although exposure to stimuli factors is insufficient for a firm's initial internationalization as it is the manager who acts as mediator, it is nonetheless an essential condition for its future foreign market engagement and sequential exporting venture as it determines the internationalization path (Tan et al., 2007). Whether decisionmakers perceive relevant stimuli or not will influence a firm's foreign market commitment (Wiedersheim-paul et al., 1978). As Leonidou et al. (2007) state research shows exporters are more favourable to motivators than non-exporters. As the European Commission (2010) shows, only $4 \%$ of EU SMEs have an export plan or intention.

Therefore the question remains; what is the effect on SMEs of home and host country based motivators in their decision to export and what is the regional effect of EU membership? What is the influence of EU regulations on exporting decisions of manufacturing SMEs from the UK? Where do these motivators stem from, the home country environment or the host country environment? The study suggests there is a critical difference in the impact of host country and home country motivators (amongst which EU membership) in managers' attitude towards initiating exporting and regionalization, particularly for sequential exporters. It also finds an association between home country motivators and exporting and a positive relationship between host country motivators and the EU market which conforms to previous research on exporting motivations and risk (Bilkey and Tesar, 1977; Reid, 1983; Wilkinson and Brouthers, 2006).

The results show that EU markets offer a clear incentive for inexperienced or risk-averse exporters despite the high level of regulations yet many managers are not aware of it. Overoptimism is linked to lower duration in business ownership (Dawson et al., 2014), and 
that is why it is significant to research the motivators of exporting rather than relying on overoptimism. For risk-averse managers, this means paying close attention to the host environment as the closer markets seem to be ideal (particularly due to psychic distance) for inexperienced SMEs. As Wiedersheim-Paul et al. (1978) note decision-makers who perform more passive activities and have less positive attitudes toward exporting are less likely to benefit financially from export strategies. The paper aims to provide a guide for a better understanding of where firms stand in their pre-export phase and readiness with regards particularly to the EU market, and where improvements in their capabilities might lie.This aids in enhancing the future use of the motivation constructs presented in this paper. According to Hollensen (2004), the stimulation is particularly important as the overall decision to initiate exports is usually made by the president or CEO of the SME.

\section{Literature review}

Looking for answers in the previous research in the area of entry-mode selection and the preexport phase it can be seen it has mostly been theoretical, disconnected, and the behavioural pre-export phase research is neglected (Anderson and Gatignon, 1986; Dunning, 1988; Hill et al., 1990; Leonidou et al., 2007; Naranayan, 2015; Tan et al., 2007). The existing empirical research has mostly focused on the manufacturing sector (Harvie and Charoenrat, 2014; Rosnan et al. 2016; Trimeche, 2003; Zucchella and Siano, 2014) or contained a mix of sectors and industries (Hemilä and Vilko, 2014). The service sector has seen a rise in research albeit smaller (Agarwal and Ramaswami, 1992; Aykol and Leonidou, 2014; Fayos Gardo' et al., 2015). As Leonidou et al. (2007) state in their review of the motivator literature, the literature on pre-export phase firm behaviour has, till now, has been non programmatic (with duplication of work), fragmented, inconsistent, and approached only partially specific motivators while neglecting other critical ones and finally did not offer an analysis of the importance of each stimulus to exporting. It is evident that unification and analysis of the most significant existing motivators within the literature and a closer look at the more recent topics of SMEs and exporting is necessary, particularly within the EU regional setting.

\section{Export research}

Export research has gone through an evolution over the past three decades from looking at why firms export (and which factors contribute to high export activity) to studying export performance (the relationship between export strategy and export performance), to comparative studies and large sample research (e.g. Zou et al., 1998; Dhanaraj and Beamish, 2003). Several recent empirical studies have examined the impact of export related activities (e.g. Albornoz et al., 2012; Becker and Egger, 2013; Keizer et al., 2002; Trimeche, 2003; Shih and Wickramasekera, 2011; Verardi and Wagner, 2012) albeit less on SMEs (e.g. El Makrini, 2015; Freeman et al., 2012; Ortiz et al., 2012).

\section{Export location research}

Location has an impact on export performance and profitability (Cerrato and Piva, 2015; Freeman et al., 2012). Regional strategy has become more significant recently for SMEs while quick and reactive managerial responses (at times without foreign market knowledge) have become potentially counter-productive (Chatterjee and Cheng Hwa, 2000). Furthermore, Rugman and Hodgetts (2001), and Rugman (2003), emphasize the importance of regionalization to business as they stress that firms are in essence regional, countering the assumption of a globalized international business status quo. 


\section{Export motivator research}

Motivational factors are amongst the most important dimensions to export readiness (Segal et al., 2005). They refer to "all those factors triggering the decision of the firm to initiate and develop export activities" (Leonidou et al., 2007). Seringhaus and Rosson (1989) divide export barriers into four large categories: motivational, informational, operational/resourcebased, and knowledge. Motivators can also be separated into proactive/reactive (e.g. foreign market knowledge/unsolicited order also known as push/pull; Leonidou et al., 2007; Tan et al., 2007) and internal/external (e.g. excess capacity/government policy; Leonidou et al., 2007); internal being those that derive from within the firm and external from the environment. Proactive motivators denote a firm's interest in exploiting a unique organizational competence or market opportunity, and reactive indicate engagement in export activities as a response to internal or external pressures (Leonidou et al., 2007). Not all home country variables are proactive, i.e. not all initiate from within the firm, such as domestic competition (Leonidou et al., 2007).

Most of the empirical research viewed the SME's involvement in international operations as an evolutionary and sequential process, based on the fundamental assumption that export activity develops from a series of incremental decisions. Theoretical development has been based mostly on the "Uppsala Internationalization Model" (Johanson and Widersheim-Paul, 1975; Johanson and Vahlne, 1977, 1990; Lynn Childs and Jin, 2014), suggesting that firms move through stages of psychological commitment as they grow from being non-exporters to being actively involved in exporting with higher commitment emphasizing knowledge gathered through experience in foreign activities, psychic distance, and the incremental resource commitment of the firm. The international expansion of firms is a learning process in which firms progressively gain international experience (Armario et al., 2008; Försgren, 2002).This model suggests that firms are instigated mainly reactively usually via an unsolicited order from the host country without taking into account that exporting can occur via planned or unplanned strategies (Crick and Spence, 2005; Melin, 1992). In addition a lot of work has been based on internal resources as instigators, the resource-based view, and managerial competence (Barney, 1991; Dhanaraj and Beamish, 2003). The Uppsala model has been challenged as lacking in explanatory power and testability (Andersen, 1993; Reid, 1983; Reilly and Sharkey Scott, 2014; Turnbull, 1987), as being overly simplified, and as being out of date (Johanson and Vahlne, 2009).

\section{Exporting SMEs and the EU common market}

SMEs are the fastest growing segment in international trade and critical to economic growth accounting for approximately $50 \%$ of global GDP and $60 \%$ of global employment (Bamiatzi and Kirchmaier, 2014; Gerlach-Kristen et al., 2015; Kushnir et al, 2010). Small firms accounted for $99.3 \%$ of all UK private sector businesses, $48 \%$ of private sector employment and $33 \%$ of private sector turnover (United Kingdom Department for Business Innovation and Skills, 2015). SMEs within the EU contribute more towards net job creation than their larger counterparts (De Kok and De Wit, 2013). Although declining in share of UK economic output and number of firms as other industries rise, the manufacturing sector still represents $44 \%$ of UK exports, and the UK remains the world's $11^{\text {th }}$ largest manufacturer (United Kingdom House of Commons Library, 2015; United Kingdom Department for Business Innovation and Skills, 2015).

With the issue of the repercussions of Britain leaving the EU growing in debate, the role of the EU as a lure for SME exporting is more and more a matter of argument. Within the context of SME internationalization for UK SMEs the EU common market is viewed as a 
significant motivator by $81 \%$ of UK SMEs and this is because of the advantages it bestows to the SME; red tape and border bureaucracy has been reduced, and trade within the EU has risen by 30\% since 1992 (European Commission, 2007). However, as Mulhern (1995) points out many of the developments of the EU common market are not favourable to SMEs necessarily, as policies are criticised as being ineffective for SMEs leading to a debate on whether SMEs are triggered by EU membership or simply proximity.

Governmental export promotion policies' results, while at times positive (Ali and Shamsuddoha, 2014) have been heavily criticised for their inefficiencies and lack of targeting (Bernard and Jensen, 2004). Nevertheless, most SMEs noted regulation as one of their biggest barriers in the EU despite the advantages in trade (see for example, Demary et al., 2016, for a list of the barriers). As SMEs in manufacturing have been hit hard by the recent crisis, can they afford to direct their efforts to the EU market regionally? What attracts them there?.There is currently no universal method to evaluate the cost to SMEs of compliance to EU regulations. Nevertheless, the attitudinal factors affecting managers can be assessed. $80 \%$ of world trade among regions is merchandise trade - that is, only $20 \%$ of world trade is in services (United Nations Conference on Trade and Development, 2014). The EU is the UK's main export destination along with the United States of America (Beleska-Spasova and Glaister, 2009).

Despite opportunities, trade flows continue to be concentrated within regions rather than between regions. 63\% of Europe's exports remain within Europe (Eurostat, 2014). In general, SMEs have fewer resources (particularly financial) to adapt to turbulence and crises and are thus the most affected by them, they thus have to adapt to these situations using varied strategies such as exporting to face the challenges (Calof, 1993; O'Rourke, 1985; Organisation for Economic Co-operation and Development, 2015). As Kahiya (2013) states, export barriers (and inversely motivators) can determine the internationalization path and speed of the SME.

Within the market entry strategy, exports represent a most common, and often initial, stage which allows SMEs to gain international experience, grow and to reduce uncertainty in foreign markets (Leonidou et al., 2007; Love and Roper, 2015; Majocchi et al, 2005; Zou et al., 1998). Therefore, exports are regarded as an optimal (Hinson and Abor, 2005), and most recurrent (Johanson and Vahlne, 1990; Jones, 2001; Rosnan et al., 2016) basis for SMEs to begin internationalization as the international expansion of SMEs is regarded as a process whose activities develop incrementally over time. As Hilmersson (2014) states, the strategy of firm internationalization can be seen as a relevant predictor of performance particularly during market turbulence.

\section{Theoretical framework and hypotheses}

The 27 variables selected from the literature, after narrowing down from 44 using principal component analysis, are presented in table 1 (e.g. excess capacity, legal restrictions, unsolicited order) and are recurring in the literature (Driscoll, 1995; Kuada and Sørensen, 2000; Leonidou et al., 2007).

[Table 1] 
The factors, as is presented below, are categorized as technological, reactive, marketing, external and internal. Following Leonidou et al. (2007)'s classification of export stimuli, the paper finds that the 44 motivators (or stimuli) assessed can be presented as 5 factors (or dimensions) and re-categorized according to their contribution to key functional areas of the organisation; the 27 final variables are higher contributors to key functional areas of the SME's organisation meaning they have been deemed by the literature as having a higher impact on the decision to export (Leonidou et al., 2007). Technological motivators are those that add to $R \& D$ and increasing value through technology, marketing motivators are those that add value through marketing, reactive motivators are external instigators associated with reactive behaviour as per the literature (Leonidou et al., 2007; Johanson and Valhne, 1990), external and internal motivators are proactive motivators yet sub divided into internal and external according to provenance, not belonging to technology or marketing or any specific sub-category. These can be seen in the theoretical framework;

[Figure 1]

In accordance with studies on export behaviour (Pan and Tse, 2000; Barkema and Drogendijk, 2007; Andersson et al., 2004) the paper is not process based (Welch and Paavilainen-Mäntymäki, 2014) but contributes to the internationalization process research using variance data with variance theory accessing present export choices at one point in time (e.g. Barkema and Drogendijk, 2007). In the paper the effect of the motivators is assessed during the year of export and as a single move. Age, as D'Angelo et al. (2013) point out, does not have a significant effect on export success. Size is measured at the present point of first export year and degree of internationalization, for example, is measured at one point in time as percentage of international to total sales (e.g. Andersson et al., 2004). The firms are classified according to degree of commitment to internationalization and export status as in Rao and Naidu (1993) where "stage" of internationalization does not denote a process but a "type" (i.e. Mode and degree of commitment). The stages are not seen as sequential per se (Wickramasekera and Oczkowski 2006), but as varying in commitment levels and are categorized accordingly. Thus, the latest entry mode of all firms used in the paper is exporting and the factors are all assessed for their influence at one point in time.

As Leonidou et al. (2007) state the effect of motivators varies in time and must be assessed at a specific point in time in accordance with a specific setting. These motivators are situational; i.e. act at one point in time (Driscoll, 1995; Kuada and Sørensen, 2000; Leonidou et al., 2007). As in the literature, following the manufacturing-services literature dichotomy mentioned above, the paper uses a holistic manufacturing setting (e.g. Weaver and Pak, 1990; Hart and Tzokas, 1999; Kennon et al., 2015) at a specific point in time (the year of the first move abroad) to study the phenomenon. The motivators tend to be home-based (Alrashidi, 2014; Leonidou et al., 2007). As Leonidou et al. (2007) state, the stimulation effort is generally (but not solely) based on reactive factors and this may lead the firm into problematic export paths. The effort should be based on proactive factors (e.g. firm-specific advantages) as each opportunity is examined carefully to ensure that it conforms to the company's goals for profits, sales and is overall strategic export plans (Soininen, 2013; Wolff et al., 2015).

Following the Uppsala model perspective common amongst SMEs (Bilkey and Tesar, 1977; Johanson and Vahlne,1977,1990) and Barney's (1991) resource-based view of internal 
competences (Dhanaraj and Beamish, 2003; Lin and Wu, 2014; Peng, 2001; Terziovski, 2010; Westhead et al., 2001), the paper investigates whether the hypothesis that proactive (home country-specific) are more prone to lead to risk-loving expansion further away from the home market and region, than reactive (host country-specific) motivators (Reid, 1983; Leonidou et al., 2007; Morschett et al., 2010) is true:

\section{H1: Home motivators are positively associated with the choice to export outside the EU}

The motivators tested lead the firm to export specifically through their direct impact. Leonidou et al., 2007 argue that firms motivated by host country pressures (or low impact motivators) are less likely to engage in exporting (particularly high commitment outside their region) due to their inertia, lack of know-how, and their being risk-averse. In particular for SMEs, sensitivity and flexibility to react to events in their surrounding network contacts are critical capabilities for successful internationalization (Zhang et al., 2014). Reactive hostcountry based external motivators lead to risk-averse strategies particularly within the EU common market (Morschett et al., 2010):

\section{H2: Host motivators are positively associated with the choice to export in an EU country}

For SMEs, acting when faced with specific opportunities and searching the environment can be a critical competitive advantage (Fiet et al., 2013). The existence of successful multinational firms and of significant, repeated, stimuli from both the home and host country associated with exporting per se can encourage innovation and expansion by smaller firms outside of their own region and reduce research costs (Tödtling and Kaufmann, 2001):

\section{H3: The selected motivators are associated with the choice to export}

[Figure 2]

Methodology-Participants The definition of SME adopted by the paper is the EU SME definition of 2003 (European Commission, 2003). The main factors determining whether an enterprise is an EU SME are:

[Table 2]

The SMEs are all independent (i.e. not subsidiaries) in manufacturing; the questionnaire was used to single out the exporters with a recent ( 5 years) latest entry into a foreign market. The year of establishment of the sample's firm ranges from 1920 to 2004, with the majority of the firms having registered with companies house (and hence been established) between 
1981 and 2004. Following the methodology, as representative sample a sample of 648 independent and registered SMEs with international activity were singled out.

As the response rate for SME surveys is not usually very high, e.g. 10-15\% (Jobber and O'Reilly, 1998; Dennis, 2003), the paper targeted all of the enterprises from the sources of data and achieved an overall response rate of $15.9 \%$ from complete questionnaires using prenotification (e.g. Jobber, 1986). Questionnaires with Likert-type scales were then sent out during the period of 2010-2011 to all the 648 independent SMEs working within manufacturing in the UK which have been singled out from the databases. The questionnaires were sent to the CEOs of each SME as strategic decision makers, in line with the research of John (1984) and Hollensen (2004) regarding selecting knowledgeable informants.

A total of 105 questionnaires were returned presenting exporting activity from a total of 648 questionnaires sent out, out of which 103 were complete and 2 were not, i.e. they had more than $30 \%$ of their data missing (Acock, 2005). The response rate achieved for the total number of sent questionnaires was satisfactory according to the literature (Leonidou, 1995; Jobber and O'Reilly, 1998).

\section{Questionnaire design}

As proven and universal constructs do not exist for these variables appropriate scales had to be constructed using the literature on SME motivators (e.g. Kim and Hwang, 1992; Leonidou et al., 2007), thus the scale of 1-7 was deemed most appropriate for the discrete variable (as seen in table 1) and 1-2 for the dichotomous variables. The international market entry mode variable was measure using a 1-5 ordinal scale increasing in resource commitment with 1 =exporting, $2=$ licensing, $3=$ franchising, $4=$ =joint-venture, $5=F D I$, and exporters singled out.

\section{Measures}

Since we were interested in identifying motivators for latest entry mode in the EU, we used principle component analysis (PCA) to reveal latent unobserved variables underlying our 47 questionnaire items. Using the Wilcoxon rank sum test, we then looked for any significant differences in the mean factor scores between these motivators in order to identify if some motivators were more likely to result in entry into the EU market. Convergent and discriminant validity was examined through the use of the Fornell-Larcker criterion (Fornell and Larcker, 1981), i.e. by comparing the average variance extracted from the latent variables to the square of correlations between the latent variables obtained using confirmatory factor analysis. Finally, internal consistency and reliability were examined using Cronbach's $\alpha$. For the entire analysis, a significance level of $\alpha \leq 0.05$ was used when attempting to reject the null hypothesis.

\section{Identifying the motivators using principle component analysis}

Principal component analysis with varimax rotation revealed 15 components with eigenvalues $>1.0$, however, the Scree plot (Figure 3) shows an elbow at five components, which we interpreted as being the: external dimension; technology dimension; research dimension; reactive dimension; and marketing dimension. Furthermore, for our sample size of 103 participants, we only interpreted factor loadings $>=|0.5|$, as recommended by Stephens (2002), resulting in 27 items in total (see Table 4 for components and item loadings). Bartlett's test of sphericity was significant, $\chi^{2}(1081)=2044, p<0.01$, providing evidence to support that the correlation matrix diverges from the identity matrix. The KaiserMeyer-Olkin (KMO) measure of sampling adequacy was an acceptable 0.6 after dropping three items with low individual KMO values prior to constructing the model.Finally, the root 
means squared residual (RMSR) was 0.09 , which is below the 0.1 threshold for an acceptable model fit.

[Figure 3]

[Table 3]

Reliability and validity

Cronbach's $\alpha$ was used to test for internal consistency and reliability of the items that make up the five components and returned the following: external dimension (alpha $=0.89$ ); research dimension $(\mathrm{alpha}=0.69)$; technology dimension $($ alpha $=0.81)$; reactive dimension $($ alpha $=0.72)$; and marketing dimension $($ alpha $=0.71)$, which are fairly reasonable scores given the subjective nature of the data. The total internal consistency for the entire questionnaire was reasonably high $($ alpha $=0.83)$, therefore the questionnaire was reliable within the acceptable limits.

Although the factor loadings are of themselves evidence to support construct validity (i.e., items load more strongly on one factor than the others), to further ensure convergent validity, we used confirmatory factor analysis with the same items from the PCA model to extract the average variances. The average variance extracted (AVE) was $>0.5$ for the external dimension (0.51), the technology dimension (0.51), and the marketing dimension (0.59), providing evidence to support satisfactory convergent validity. The same was not true for the research (0.4) and reactive (0.2) dimensions. These two variables were therefore not considered for further analysis. Discriminant validity was assessed by comparing the AVE to the squared factor correlations as shown in correlation matrix in table 5. In all cases the AVE $>$ the squared factor correlations, therefore our model demonstrated discriminant validity. Overall we report that although the model is valid, it has room for improvement.

[Table 4]

\section{Findings}

To investigate the EU effect, the data was split into two groups; those whose latest market entry was in the EU; and those whose latest market entry was not in the EU (a categorical independent variable with two levels). From there any significant differences in average factor scores retrieved from our principle component analysis between the two groups were assessed using the Wilcoxon rank sum test. The results reveal that participants whose latest entry was not in the EU scored significantly higher in the factor scorings for the external dimension than participants whose latest entry was in the $E U(W=437, p=0.02)$. There were no significant differences between the two groups for the other components. A priori power analysis reveals that for a two-tailed t-test, a medium effect size $(d=0.5)$, a significance level of $\alpha=0.05$, and a power (1- $\beta$ ) of 0.7 , the required sample size is 100 ; Thus making the sample size of 103 adequate (e.g. Chelilah et al., 2010; Chowdhury et al., 2015).

Correlation analysis was also run against the SMEs' latest entry mode selected i.e. exporting as in previous SME work (Albornoz et al., 2012; Keizer et al., 2002; Kmieciak et al, 2012; Shih and Wickramasekera, 2011; Yee-Loong Chong et al., 2014). The results of the correlation analysis can be seen in tables 6 and 7 . 


\section{Discussion} * the results indicated with an asterisk are presented with caution since they did not load into any of our five significant
components, in addition our sample size was fairly small.

\section{H 1: Home motivators are positively associated with choice to export outside the EU}

Impact of political stability UK/Economic stability UK/Legal restriction UK/Legal incentives UK

The results reveal that participants whose latest entry was not in the EU scored significantly higher in the factor scorings for the external dimension than participants whose latest entry was in the EU ( $\mathrm{W}=437, \mathrm{p}=0.02)$. This can, in part, be explained by the importance of external factors, (eg. Red tape, policy and bureaucracy), towards exporting in the EU. With favourable external conditions (government policy, legislation, setup costs, etc) the SMEs' liability of foreignness can decrease allowing for many SMEs to be more risk prone and venture beyond their region. As a matter of fact the lack of adequate public support is considered a barrier for European SMEs more with reference to EU markets than with reference to third markets. This is possibly related to the fact that generally somewhat larger and more experienced SMEs are active in non-EU markets and to the fact that $20 \%$ of SMEs are not aware of public support programs available to them (European Commission, 2010).

\section{Extent of $R \& D /$ Extent of new external technology*}

The results show how (internal) research and development and use of new external technology are positively associated with the choice to export outside the EU; just like adopting a new technology, a high level of R\&D can give the firm an advantage in creating innovative products which can be irreplicable or patented and thus creating also a competitive advantage for the firm giving proactive managers the edge they need to expand abroad. Coe and Helpman (1995) find a positive and statistically significant effect of (domestic) R\&D stock on total factor productivity growth.

\section{Foreign market knowledge}

Foreign market knowledge is positively associated with the firm exporting outside of an EU country. The variable foreign market knowledge differs from international experience, as foreign market knowledge is specific to foreign markets, as opposed to the general experience from the process of internationalization (Root, 1982). Foreign market knowledge is a proactive variable, which like international experience, can give a competitive advantage to the firm allowing it to bypass obstacles such as costs, adaptation, and researching markets (Armario et al., 2008).

According to Aharoni (1966), the corporate decision making approach on foreign direct investment by SMEs is a managerial process. As Zou et al. (1998) state, export performance and success are under control of management more than external factors. Musteen et al., 
(2014) note how foreign market knowledge prior to the first international venture had a positive impact on venture performance.

Strengths of prices of products*

Strengths of prices of products (i.e. the perceived level of elasticity of price by the manager) is negatively associated to exporting within the EU. As with most host country motivators, this is the opposite of what occurs with the home country equivalent motivator. This is because of the fact that host country motivators affect the firm by "pulling" it whilst home country motivators affect by "pushing" the firm. If a firm manages to succeed in having a ready market abroad where its products are already accepted and demand is high then it may even consider internationalizing there regardless of the situation at home unless it is better than the opportunity abroad and cannot risk any move (in terms of resources) or unless it is too bad in the home country and the firm cannot afford it (Majocchi and Zuchella, 2003).

\section{H 2: Host motivators are positively associated with the choice to export in an EU country}

\section{Impact of political stability host/Legal restrictions in the host country/ Economic stability in} the host country

Legal, political and economic restrictions are the equivalent of their home counterpart but in a foreign country, acting as a barrier or inducement to the firm. The variables are positively associated with the SME's decision to internationalize into a foreign country within the EU. This is due to the fact that they are proactive "pull" variables and as the situation in the host country worsens for the proactive SME so do the opportunities it has to enter this market, and vice versa. It's the pull factor that attracts the firm towards the country (Dawson and Henley, 2012; Dunning and Lundan, 2008) but it can also become a push factor if the legal restrictions become negative such as high taxation for foreign firms or high red tape for foreign firms coming to do business in the country.

Market potential of the host country*

The variable shows a positive association with the decision to export in the EU. Like its UK counterpart, it deals with the potential of the market (i.e. demand and purchasing power) but in the host country. As the pull factor of the host market potential rises, the chance of the firm internationalizing beyond the EU and taking a chance into a further away market is higher. As the OECD (2009) states, SME managers in the UK seem to be motivated reactively mainly by the search for a larger market.

Acceptability of the firm's products in the host country*

Acceptability of products in the host country is positively associated with the choice to export inside the EU, showing that as the acceptability of products in a host country rises, the chances of the firm exporting outside the EU will not necessarily rise. It seems the acceptability of the firm's products is not a strong enough motivator to warrant the SME's involvement and risk in regionally foreign markets (unlike strengths of prices), particularly for inexperienced SMEs. In the case of SMEs it is highly unlikely that the firm would reach the point of having a large market share due to its limited resources and, at times, size (Calof, 1993; O'Rourke, 1985). This is also why firm size could be a barrier to export intensity for some SMEs, albeit not for all (Bonaccorsi, 1992). 
H3: The selected motivators are directly associated with the choice to export

Firm's first entry mode choice*

The SME's first ever international entry mode seems shows an association with the choice to export. It seems the SME's first steps can affect its sequential choices thus challenging the arguments that internationalization involves incremental learning (Johanson and Vahlne, $1990 ; 2009)$ and strategy does not involve bias from the manager's perspective. As foreign market knowledge is also associated with exporting it seems the manager's knowledge may come from previous moves abroad which affect his/her consequent decisions.

\section{Competitor beginning to export}

As for the pull motivation of an unsolicited order, the push motivation of a competitor in the home market beginning to export is associated with the choice to export. It is unclear whether it can lead to internationalization beyond the EU markets but it is evident that it can lead to stimulation of exporting (Lynn Childs and Jin, 2014; Johanson and Vahlne, 1977, 1990; Johanson and Widersheim-Paul, 1975).

\section{Government policy*}

This motivator is associated with the choice to export. As government policy is (mostly) considered a barrier (Leonidou, 2004), it is expected it will show association. Government policy can determine the final entry mode that the firm selects and can force the firm to change or stop its plans for expansion (Ali and Shamsuddoha, 2014) as a moderator. For a firm ready to internationalize motivated by a specific motivator, such as a firm-specific advantage, a change in government policy towards higher levels of barriers would alter the firm's strategy and slow down its internationalization, if not end it, according to the costs it can bear, to the level of experience of the manager or the strength of its competitive advantage (Bernard and Jensen, 2004).

\section{EU membership of the $U K$}

This motivator showed an association with the choice to export. As mentioned above, the EU common market and region can provide an incentive for many SMEs to internationalize, particularly for newcomers or resource constrained firms (Beleska-Spasova and Glaister, 2009; Freeman et al., 2012). This could provide interesting findings for SME policy and regionalization as it is evident that EU membership is a stimulus for UK SMEs to export into the EU markets.

\section{Conclusions}

Summary and theoretical implications

It was hypothesized that home country motivators would positively affect the choice to internationalize outside of the EU whilst host country motivators would positively affect the choice to internationalize in an EU country. The findings of this paper reinforce and extend previous work on exporting and export promotion such as the work of Leonidou (2007). They contribute not only to the academic debate on export theory by providing new deterministic 
measures for motivator variables (Dobbs and Hamilton, 2007), but also provide input into a real world dilemma such as the importance of EU membership to SMEs exporting. The paper provides a platform for the future use of motivational constructs in export motivation research.

The paper has demonstrated the significance to export readiness and direction (in the current climate) of managers' perceptions of government policy, legal restrictions, economic stability and EU membership to SME exporting; and how it can shape results and research costs by avoiding premature export decisions based on low impact motivators or reactive haste decisions.

\section{Practical implications}

Boosting, researching and encouraging the international activities of SMEs is of vital importance for managers and policy itself (Hilmersson, 2014; Knight, 2000; Luostarinen and Welch, 1990) particularly exporting (Hinson and Abor, 2005). According to the Organization of Economic Co-operation and Development (2009) SME managers perceive the lack of time to deal with internationalization as a significant barrier, the findings aim to speed up this process and provide clarity. Thus, taking full advantage of the EU membership in the current climate is important for risk-averse managers willing to export, as Cerrato and Piva (2015) state there is a positive relationship between a global reach and profitability.

\section{Limitations}

It would be interesting, with a larger sample, to investigate the differences of the effects of motivators on SMEs, then on medium sized firms and compare them amongst each other including subsidiaries. The same applies for cross-regional country studies. 
References

Acock, A.C. (2005), "Working with missing values", Journal of Marriage and Family, Vol.67 No.4, pp.10121028.

Agarwal, S. and Ramaswami, S.N. (1992), "Choice of foreign market entry mode: Impact of ownership, location and internalization factors", Journal of International Business Studies, pp.1-27.

Aharoni, Y. (1966), The Foreign Investment Decision Process, Vol. 403., Harvard University Press, Boston.

Albornoz, F., Pardo, H.F.C., Corcos, G. and Ornelas, E. (2012), "Sequential exporting", Journal of International Economics, Vol.88 No.1, pp.17-31.

Ali, M.Y. and Shamsuddoha, A.K. (2014), "Impact of export promotion programs on SME export performance: empirical evidence from an emerging nation", in Research Handbook on Export Marketing, Julian C. (Ed.), Cheltenham, UK.

Alrashidi, Y.A. (2014), "Exporting Motivations: Differences Between Manufacturing SMES Operating Within Emerging And Advanced Markets", International Journal of Arts and Sciences, Vol.7 No.4, p.9.

Andersen, O. (1993), "On the internationalization process of firms: a critical analysis", Journal of International Business Studies, Vol.24 No.2, pp.209-231.

Anderson, E. and Gatignon, H. (1986), "Modes of foreign entry: A transaction cost analysis and propositions", Journal of International Business Studies, Vol.17 No.3, pp.1-26.

Andersson, S., Gabrielsson, J., and Wictor, I. (2004). International activities in small firms: examining factors influencing the internationalization and export growth of small firms. Canadian Journal of Administrative Sciences/Revue Canadienne des Sciences de l'Administration, 21(1), 22-34.

Armario, J.M., Ruiz, D.M. and Armario, E.M. (2008), "Market orientation and internationalization in small and medium-sized enterprises", Journal of Small Business Management, Vol.46 No.4, pp.485-511.

Aykol, B. and Leonidou, L.C. (2014), "Researching the green practices of smaller service firms: A theoretical, methodological, and empirical assessment", Journal of Small Business Management, Vol.53 No.4, pp.1264-1288.

Bamiatzi, V.C. and Kirchmaier, T. (2014), "Strategies for superior performance under adverse conditions: A focus on small and medium-sized high-growth firms", International Small Business Journal, Vol.32 No.3, pp.259-284.

Barkema, H. G., and Drogendijk, R. (2007). Internationalising in small, incremental or larger steps?. Journal of International Business Studies, Vol.38 No.7, pp.1132-1148.

Barney, J. (1991), "Firm resources and sustained competitive advantage", Journal of Management, Vol.17 No.1, pp.99-120.

Becker, S.O. and Egger, P.H. (2013), "Endogenous product versus process innovation and a firm's propensity to export", Empirical Economics, Vol.44 No.1, pp.329-354.

Beleska-Spasova, E. and Glaister, K.W. (2009), "The geography of British exports: Country-level versus firmlevel evidence", European Management Journal, Vol.27 No.5, pp.295-304.

Bell, J., McNaughton, R. and Young, S. (2001), "Born-again global firms: An extension to the 'born global' phenomenon", Journal of International Management, Vol.7 No.3, pp.173-189.

Bernard, A.B. and Jensen, J.B. (2004), "Why some firms export", Review of Economics and Statistics, Vol.86 No.2, pp.561-569.

Bilkey, W.J. and Tesar, G. (1977), "The export behavior of smaller-sized Wisconsin manufacturing firms", Journal of International Business Studies, Vol.8 No.1, pp.93-98.

Bonaccorsi, A. (1992), "On the relationship between firm size and export intensity", Journal of International Business Studies, Vol.23 No.4, pp.605-635.

Calof, J.L. (1993), "The impact of size on internationalization", Journal of Small Business Management, Vol.31 No.4, pp.60-69.

Cerrato, D., and Piva, M. (2015), "The effect of global orientation on the performance of international new ventures: evidence from Italy", Management International Review, Vol.55 No.6, pp.857-883.

Chatterjee, S. R., and Lim, C. H. (2000), "Regionalization strategies of the SME sector: An empirical study of Singapore managers", Journal of International Business and Entrepreneurship, Vol.8 No.2, pp.15-31.

Chellilah, S., Sulaiman, M. and Yusoff, Y. M. (2010), "Internationalization and performance: Small and medium enterprises (SMEs) in Malaysia", International Journal of Business and Management, Vol.5 No.6, pp.27.

Chowdhury, M.S.A., Azam, M.K.G. and Islam, S. (2015), "Problems and Prospects of SME Financing in Bangladesh", Asian Business Review, Vol.2 No.2, pp.51-58.

Coe, D.T. and Helpman, E. (1995), "International r\&d spillovers", European Economic Review, Vol.39 No.5, pp.859-887.

Crick, D. and Spence, M. (2005), "The internationalisation of 'high performing' UK high-tech SMEs: a study of planned and unplanned strategies", International Business Review, Vol.14 No.2, pp.167-185. 
D'Angelo, A., Majocchi, A., Zucchella, A., and Buck, T. (2013), "Geographical pathways for SME internationalization: insights from an Italian sample”, International Marketing Review, Vol.30 No.2, pp. 80-105.

Dawson, C., De Meza, D., Henley, A. and Arabsheibani, G.R. (2014), "Entrepreneurship: Cause and Consequence of Financial Optimism", Journal of Economics and Management Strategy, Vol.23 No.4, pp.717-742.

Dawson, C. and Henley, A. (2012), “"Push" versus "pull” entrepreneurship: an ambiguous distinction?", International Journal of Entrepreneurial Behavior and Research, Vol.18 No.6, pp.697719.

De Kok, J., and De Wit, G. (2013), “Do small businesses create more jobs? New evidence for Europe”, No. H201203. EIM Business and Policy Research.

Demary, M., Hornik, J., and Watfe, G. (2016), SME Financing in the EU: Moving beyond one-size-fits-all, No. 40, European Economic Studies Department, College of Europe.

Dennis, W.J. (2003), "Raising response rates in mail surveys of small business owners: Results of an experiment", Journal of Small Business Management, Vol.41 No.3, pp.278.

Dhanaraj, C. and Beamish, P.W. (2003),"A resource-based approach to the study of export performance", Journal of Small Business Management, Vol.41 No. 3, pp.242-261.

Dunning, J.H. (1988), "The eclectic paradigm of international production: a restatement and some possible extensions", Journal of International Business Studies, Vol.19 No.1, pp.1-31.

Dunning, J.H. and Lundan, S.M. (2008), Multinational Enterprises and the Global Economy, Edward Elgar Publishing, Cornwall.

Driscoll, A. (1995), "Foreign market entry methods: a mode choice framework". In Paliwoda S.J. and Ryans R.K., International Marketing Reader, Routledge, London, pp.15-34.

Dobbs, M., and Hamilton, R. T. (2007). "Small business growth: recent evidence and new directions", International Journal of Entrepreneurial Behavior and Research, Vol.13 No.5, pp.296322.

Edmunds, S. E., and Khoury, S. J. (1986), "Exports: A necessary ingredient in the growth of small business firms", Journal of Small Business Management, Vol.24, pp.54.

El Makrini, H. (2015), "How does management perceive export success? An empirical study of Moroccan SMEs", Business Process Management Journal, Vol.21 No.1, pp.126-151.

Experian (2015), "Experian Marketing Services" available at: http://www.experian.co.uk - (accessed 27 April 2015).

European Commission (2003), “What is an SME?”,available at: http://ec.europa.eu/growth/smes/businessfriendly-environment/sme-definition/index_en.htm (accessed 18 May 2015).

European Commission, (2007), "EU Single market - benefits", available at: http://www.eubusiness.com/topics/sme/eu-single-market-guide/ (accessed 25 March 2015).

European Commission (2010), Internationalisation of European SMEs, DG Enterprise and Industry, European Commission, Brussels.

Eurostat (2014), International trade in goods in 2014, News Release, 55/2015, Brussels

Fayos Gardó, T., Calderón García, H. and Mollá Descals, A. (2015), "Internationalization of SME retailer: barriers and the role of public support organizations", International Journal of Retail and Distribution Management, Vol.43 No.2, pp.183-200.

Fiet, J.O., Norton, W.I. and Clouse, V.G. (2013), "Search and discovery by repeatedly successful entrepreneurs", International Small Business Journal, Vol.31 No.8, pp.890-913.

Fillis, I. (2001), "Small firm internationalisation: an investigative survey and future research directions", Management Decision, Vol.39 No.9, pp.767-783.

Fornell, C., and Larcker, D. F. (1981), "Evaluating structural equation models with unobservable variables and measurement error", Journal of Marketing Research, pp.39-50.

Försgren, M. (2002), "The concept of learning in the Uppsala internationalization process model: a critical review”, International Business Review, Vol.11 No.3, pp.257-277.

Freeman, J., Styles, C. and Lawley, M. (2012), "Does firm location make a difference to the export performance of SMEs?”, International Marketing Review, Vol.29 No.1, pp.88-113.

Gerlach-Kristen, P., O'Connell, B. and O'Toole, C. (2015), "Do Credit Constraints Affect SME Investment and Employment?", The Economic and Social Review, Vol.46 No.1, pp.51-86.

Harvie, C. and Charoenrat, T. (2015), "SMEs and the Rise of Global Value Chains" in Integrating SMEs Into Global Value Chains, Asian Development Bank institute, Manila.

Hart, S., and Tzokas, N. (1999). The impact of marketing research activity on SME export performance: evidence from the UK. Journal of Small Business Management, Vol.37 No.2, pp.63.

Hemilä, J. and Vilko, J. (2015), "The development of a service supply chain model for a manufacturing SME”, The International Journal of Logistics Management, Vol.26 No.3, pp.517-542. 
Hill, C.W., Hwang, P. and Kim, W.C. (1990), "An eclectic theory of the choice of international entry mode", Strategic Management Journal, Vol.11 No.2, pp.117-128.

Hilmersson, M. (2014), "Small and medium-sized enterprise internationalisation strategy and performance in times of market turbulence", International Small Business Journal, Vol.32 No.4, pp.386-400.

Hinson, R. and Abor, J. (2005), "Internationalizing SME nontraditional exporters and their internet use idiosyncrasies", Perspectives on Global Development and Technology, Vol.4 No.2, pp.229-244.

Jobber, D. (1986), "Improving response rates in industrial mail surveys",Industrial Marketing Management, Vol.15 No.3, pp.183-195.

Jobber, D. and O'Reilly, D. (1998), "Industrial mail surveys: A methodological update", Industrial Marketing Management, Vol.27 No.2, pp.95-107.

Johanson, J. and Vahlne, J.E. (1977), "The internationalization process of the firm-a model of knowledge development and increasing foreign market commitments", Journal of International Business Studies, Vol.8 No.1, pp.23-32.

Johanson, J. and Vahlne, J.E. (1990), "The mechanism of internationalisation", International Marketing Review, Vol. 7 No.4, pp.11-24.

Johanson, J. and Vahlne, J.E. (2009), “The Uppsala internationalization process model revisited: From liability of foreignness to liability of outsidership", Journal of International Business Studies, Vol.40 No.9, pp.1411-1431.

Johanson, J. and Wiedersheim-Paul, F. (1975), "The internationalization of the firm-four swedish cases 1", Journal of Management Studies, Vol.12 No.3, pp.305-323.

John, G. (1984), "An empirical investigation of some antecedents of opportunism in a marketing channel", Journal of Marketing Research, Vol.21 No.3, pp.278-289.

Jones, M.V. (2001), "First steps in internationalisation: Concepts and evidence from a sample of small hightechnology firms", Journal of International Management, Vol.7 No.3, pp.191-210.

Kahiya, E.T. (2013), "Export barriers and path to internationalization: A comparison of conventional enterprises and international new ventures", Journal of International Entrepreneurship, Vol.11 No.1, pp.3-29.

Katsikeas, C. S., and Piercy, N. F. (1993). "Long-term export stimuli and firm characteristics in a European LDC”. Journal of International Marketing, pp.23-47.

Keizer, J.A., Dijkstra, L. and Halman, J.I. (2002), "Explaining innovative efforts of SMEs.: An exploratory survey among SMEs in the mechanical and electrical engineering sector in The Netherlands", Technovation, Vol.22 No.1, pp.1-13.

Kennon, D., Schutte, C. S., and Lutters, E. (2015). An alternative view to assessing antifragility in an organisation: A case study in a manufacturing SME. CIRP Annals-Manufacturing Technology, Vol.64 No.1, pp.177-180.

Kim W.C. and Hwang, P. (1992), "Global strategy and multinationals' entry mode choice", Journal of International Business Studies, Vol.23 No.1, pp.29-53.

Kmieciak, R., Michna, A. and Meczynska, A. (2012), "Innovativeness, empowerment and IT capability: evidence from SMEs", Industrial Management and Data Systems, Vol.112 No.5, pp.707-728.

Knight, G. (2000), "Entrepreneurship and marketing strategy: The SME under globalization", Journal of International Marketing, Vol.8 No.2, pp.12-32.

Knight, G.A. and Cavusgil, S.T. (2004), "Innovation, organizational capabilities, and the born-global firm”, Journal of International Business Studies, Vol.35 No.2, pp.124-141.

Kuada, J. and Sørensen, O.J. (2000), Internationalization of Companies From Developing Countries, The Haworth Press Inc., New York, NY.

Kushnir, K., Mirmulstein, M.L. and Ramalho, R. (2010), "Micro, small, and medium enterprises around the world: how many are there, and what affects the count", Washington: World Bank/IFC MSME Country Indicators Analysis Note.

Leonidou, L.C. (1995), "Export stimulation research: review, evaluation and integration. International Business Review, Vol.4 No.2, pp.133-156.

Leonidou, L.C. (2004), “An analysis of the barriers hindering small business export development", Journal of Small Business Management, Vol.42 No.3, pp.279-302.

Leonidou, L.C., Katsikeas, C.S., Palihawadana, D. and Spyropoulou, S. (2007), "An analytical review of the factors stimulating smaller firms to export: Implications for policy-makers", International Marketing Review, Vol.24 No.6, pp.735-770.

Lin, Y. and Wu, L.Y. (2014), "Exploring the role of dynamic capabilities in firm performance under the resource-based view framework", Journal of Business Research, Vol.67 No.3, pp.407-413.

Love, J.H. and Roper, S. (2015), "SME innovation, exporting and growth: A review of existing evidence", International Small Business Journal, Vol.33 No.1, pp.28-48.

Luostarinen, R. and Welch, L. (1990), International Business Operations. KY Book Store, Helsinki. 
Lynn Childs, M. and Jin, B. (2014), "Is Uppsala model valid to fashion retailers? An analysis from internationalisation patterns of fast fashion retailers", Journal of Fashion Marketing and Management, Vol.18 No.1, pp.36-51.

Majocchi, A., Bacchiocchi, E. and Mayrhofer, U. (2005), "Firm size, business experience and export intensity in SMEs: A longitudinal approach to complex relationships", International Business Review, Vol.14 No.6, pp.719-738.

Majocchi, A. and Zucchella, A. (2003), "Internationalization and performance findings from a set of Italian SMEs", International Small Business Journal, Vol.21 No.3, pp.249-268.

Melin, L. (1992), "Internationalization as a strategy process". Strategic Management Journal, Vol.13 No.99, pp.99-99.

Morgan, R. E. and Katsikeas, C. S. (1997), “Obstacles to export initiation and expansion”, Omega, Vol.25 No.6, pp.677-690.

Morschett, D., Schramm-Klein, H., and Swoboda, B. (2010)., "Decades of research on market entry modes: What do we really know about external antecedents of entry mode choice?", Journal of International Management, Vol.16 No.1, pp.60-77.

Mulhern, A. (1995), "The SME sector in Europe: A broad perspective", Journal of small business management, Vol.33 No.3, pp.83.

Musteen, M., Datta, D. K., and Butts, M. M. (2014), "Do international networks and foreign market knowledge facilitate SME internationalization? Evidence from the Czech Republic", Entrepreneurship Theory and Practice, Vol.38 No.4, pp.749-774.

Narayanan, V. (2015), "Export Barriers for Small and Medium-sized Enterprises: A Literature Review based on Leonidou's Model", Entrepreneurial Business and Economics Review, Vol.3 No. 2, pp.105-123.

Organization for Economic Co-operation and Development (2015), Financing SMEs and Entrepreneurs 2015, OECD 2015, Paris.

Organization for Economic Co-operation and Development (2009), "Top Barriers and Drivers to SME Internationalisation", Report by the OECD Working Party on SMEs and Entrepreneurship, OECD.

O'Rourke, A.D. (1985), "Differences in exporting practices, attitudes and problems by size of firm", $\underline{\text { American }}$ Journal of Small Business, Vol. 9 No. 3, pp.25-29.

Ortiz, R.F., Ortiz, J.A. and Ramirez, A.M. (2012), "How does management perceive exporting? An empirical study of SMEs", Engineering Economics, Vol.23 No.2, pp.200-208.

Oviatt, B.M. and McDougall, P.P., (1994), "Toward a theory of international new ventures", Journal of International Business Studies, Vol.25 No.1, pp.45-64.

Peng, M.W., (2001), "The resource-based view and international business", Journal of Management, Vol.27 No.6, pp.803-829.

Rao, T. R., and Naidu, G. M. (1993), “Are the stages of internationalization empirically supportable?”. Journal of Global Marketing, Vol. 6 No.1-2, pp.147-170.

Reid, S. (1983), "Firm internationalization, transaction costs and strategic choice", International marketing review, Vol.1 No.2, pp.44-56.

Reilly, M. and Sharkey Scott, P. (2014), "Internationalising family run business: Overcoming Conflict, embracing cohesion and the role of entrepreneurship", in Academy of International Business (UKI) Conference Proceedings.

Root, F.R. (1982), Foreign Market Entry Strategies. Amacom, New York, NY.

Rosnan, H., Saihani, S.B., Yusoff, N. and Daud, N.M., (2016), "Export readiness among small-and mediumsized enterprises in Malaysia", in Proceedings of the 1st AAGBS International Conference on Business Management 2014 (AiCoBM 2014), Springer, Singapore, pp.57-64.

Rugman, A. M. (2003), "Regional strategy and the demise of globalization", Journal of International Management, Vol.9 No.4, pp.409-417.

Rugman, A., and Hodgetts, R. (2001), “The end of global strategy”, European Management Journal, Vol.19 No.4, 333-343.

Segal G., Borgia D. and Schoenfeld J., (2005) "The motivation to become an entrepreneur", International Journal of Entrepreneurial Behavior and Research, Vol. 11 No.1, pp.42 - 57.

Seringhaus F. and Rosson P. (1989), Government Export Promotion: a Global Perspective, Routledge, London.

Shih, T.Y. and Wickramasekera, R. (2011), "Export decisions within Taiwanese electrical and electronic SMEs: The role of management characteristics and attitudes", Asia Pacific Journal of Management, Vol.28 No.2, pp.353-377.

Soininen J.S. , Puumalainen K. , Sjögrén H. , Syrjä P. , Durst S. (2013), "Entrepreneurial orientation in small firms - values-attitudes-behavior approach", International Journal of Entrepreneurial Behavior and Research, Vol. 19 No. 6, pp.611 - 632.

Stevens, J. (2002), Applied Multivariate Statistics for the Social Sciences, (4th Edition), Mahwah, NJ: Lawrence Erlbaum Associates. 
Sullivan, D., and Bauerschmidt, A. (1990) “Incremental internationalization: a test of Johanson and Vahlne's thesis", Management International Review, pp.19-30.

Tan, A., Brewer, P. and Liesch, P. (2014), "Causes of rigidity in SMEs' export commencement decision". in 40th Annual Conference of the European International Business Academy (EIBA): The Future of Global Organizing, Uppsala University, Stockholm.

Terziovski, M. (2010), "Innovation practice and its performance implications in small and medium enterprises (SMEs) in the manufacturing sector: a resource-based view", Strategic Management Journal, Vol.31 No.8, pp.892-902.

Tödtling, F. and Kaufmann, A. (2001), "The role of the region for innovation activities of SMEs", European Urban and Regional Studies, Vol.8 No.3, pp.203-215.

Trimeche, M., (2003), "Variables Affecting the Firm's Export Performance: Exploring the Japanese Managerial Perceptions", Journal of International Marketing and Marketing Research, Vol.28 No.1, pp.3-24.

Turnbull, P.W. (1987), "A challenge to the stages theory of the internationalization process" in Managing Export Entry and Expansion, Rosson P.J. and Reid S. (Eds.), Praeger publishers, New York, NY.

United Kingdom Department for Business Innovation and Skills. (2015), Statistical Release. URN 15/92, London.

United Kingdom House of Commons Library. (2015), Manufacturing: Statistics and Policy. Briefing Paper.No.01942, London.

United Nations Conference on Trade and Development (2014), Key Statistics and Trends in International Trade, United Nations Publications.

Verardi, V. and Wagner, J. (2012), "Productivity Premia for German Manufacturing Firms Exporting to the Euro-Area and Beyond: First Evidence from Robust Fixed Effects Estimations", The World Economy, Vol.35 No.6, pp.694-712.

Weaver, K. M., and Pak, J. M. (1990). Export behaviour and attitudes of small-and medium-sized Korean manufacturing firms. International Small Business Journal, Vol.8 No.4, pp.59-70.

Welch, C. and Paavilainen-Mäntymäki, E. (2014), "Putting process (back) in: research on the internationalization process of the firm", International Journal of Management Reviews, Vol.16, pp.223.

Westhead, P., Wright, M. and Ucbasaran, D. (2001), "The internationalization of new and small firms: A resource-based view", Journal of Business Venturing, Vol.16 No.4, pp.333-358.

Wickramasekera, R., and Oczkowski, E. (2006). "Stage models re-visited: a measure of the stage of internationalisation of a firm". Management International Review, Vol.46 No.1, pp.39-55.

Wiedersheim-Paul, F., Olson, H. C., and Welch, L. S. (1978) "Pre-export activity: The first step in internationalization", Journal of International Business Studies, pp.47-58.

Wilkinson, T., and Brouthers, L.E. (2006), "Trade promotion and SME export performance", International Business Review, Vol.15 No.3, pp.233-252.

Wolff J., Pett T. and Ring J. (2015), "Small firm growth as a function of both learning orientation and entrepreneurial orientation: An empirical analysis", International Journal of Entrepreneurial Behavior and Research, Vol.21 No.5, pp.709- 730 .

Yee-Loong Chong, A., Ooi, K.B., Bao, H. and Lin, B. (2014) "Can e-business adoption be influenced by knowledge management? An empirical analysis of Malaysian SMEs”, Journal of Knowledge Management, Vol.18 No.1, pp.121-136.

Zhang, X., Ma, X., Wang, Y. and Wang, Y. (2014), "How can emerging market small and medium-sized enterprises maximise internationalisation benefits? The moderating effect of organisational flexibility”, International Small Business Journal, Vol.32 No.6, pp.667-692.

Zucchella, A., and Siano, A. (2014), "Internationalization and innovation as resources for SME growth in foreign markets: a focus on textile and clothing firms in the Campania Region", International Studies of Management and Organization, Vol.44 No.1,pp.21-41.

Zou, S., Taylor, C.R. and Osland, G.E. (1998), "The EXPERF scale: a cross-national generalized export performance measure", Journal of international Marketing, Vol.6 No.3, pp.37-58. 
Table 1 Motivators tested and their scales

\begin{tabular}{lr} 
Motivator & Scale \\
\hline Latest country entered was EU?, & $1-2$ \\
Firm's latest foreign market entry mode & $1-5$
\end{tabular}

Firm level stimuli - In-house research, Uniqueness of products, Excess capacity, Unsold inventories, 1-7 Capability to develop products, , Extent of customization, Extent of new technology combinations, Extent of new in-house technology, Extent of R\&D, Servicing products, Understanding of customers,

External stimuli - Economic stability UK, Economic stability HOST, Legal restrictions UK, Legal restrictions HOST, Legal incentives UK, Acceptability of firm's products UK, Acceptability of firm's products HOST, Market potential UK, competitor beginning to export, increased domestic competition, Impact of political stability UK, Impact of political stability HOST,

Managerial stimuli - Decision maker's knowledge of foreign markets, Quality of management

Table 2 EU SME definition criteria

\begin{tabular}{|l|l|l|l|l|}
\hline Company category & Staff headcount & Turnover & Or & Balance sheet total \\
\hline Medium-sized & $<250$ & $\leq € 50 \mathrm{~m}$ & $\leq € 43 \mathrm{~m}$ \\
\hline Small & $<50$ & $\leq € 10 \mathrm{~m}$ & $\leq € 10 \mathrm{~m}$ \\
\hline Micro & $<10$ & $\leq € 2 \mathrm{~m}$ & $\leq € 2 \mathrm{~m}$ \\
\hline
\end{tabular}


Table 3 Loadings and dimensions

Item loadings

\begin{tabular}{|c|c|c|}
\hline External & Item & Loading \\
\hline Dimentionta & $\begin{array}{l}\text { Impact of political } \\
\text { stability UK }\end{array}$ & .74 \\
\hline & $\begin{array}{l}\text { Impact of political } \\
\text { stability host }\end{array}$ & .79 \\
\hline & $\begin{array}{l}\text { Economic stability } \\
\text { UK }\end{array}$ & .76 \\
\hline & $\begin{array}{l}\text { Economic stability } \\
\text { host }\end{array}$ & .77 \\
\hline & Legal restriction UK & .73 \\
\hline & Legal restriction host & .79 \\
\hline & Legal incentives UK & .61 \\
\hline Technology & Item & Loading \\
\hline DIIIU⿴囗十⺝ & Uniqueness & .53 \\
\hline & $\begin{array}{l}\text { Capability to develop } \\
\text { products }\end{array}$ & .66 \\
\hline & $\begin{array}{l}\text { Extent of } \\
\text { customisation }\end{array}$ & .55 \\
\hline & $\begin{array}{l}\text { Extent of new } \\
\text { technology } \\
\text { combinations }\end{array}$ & .72 \\
\hline & $\begin{array}{l}\text { Extent of new in- } \\
\text { house technology }\end{array}$ & .83 \\
\hline & Extend of R.D. & .69 \\
\hline Research & Item & Loading \\
\hline & Servicing products & .63 \\
\hline & $\begin{array}{l}\text { Quality of } \\
\text { management }\end{array}$ & .66 \\
\hline & $\begin{array}{l}\text { Knowledge of } \\
\text { foreign markets }\end{array}$ & .64 \\
\hline & $\begin{array}{l}\text { Understanding of } \\
\text { customers }\end{array}$ & .67 \\
\hline & In house research & .66 \\
\hline Reactive & Item & Loading \\
\hline & $\begin{array}{l}\text { Competitor } \\
\text { beginning to export }\end{array}$ & .56 \\
\hline & $\begin{array}{l}\text { Accumulation of } \\
\text { unsold inventories }\end{array}$ & .75 \\
\hline & Excess capacity & .5 \\
\hline & $\begin{array}{l}\text { Increased domestic } \\
\text { competition }\end{array}$ & .64 \\
\hline & Unsold inventories & .73 \\
\hline
\end{tabular}


Marketing

Item

Loading

Dimension

Acceptability of firm's products UK

.7

Acceptability of firm's products Host

.53

Market potential UK

.5

Table 4 - Factor correlations and average variance extracted for external, technology, and marketing dimensions

\begin{tabular}{llll}
\hline & External & Technology & Marketing \\
\hline External & $0.51(\mathrm{AVE})$ & & \\
Technology & 0.2 & $0.51(\mathrm{AVE})$ & \\
Marketing & 0.23 & 0.06 & 0.59 (AVE) \\
\hline
\end{tabular}

http://mc.manuscriptcentral.com/ijebr 
Table 5 Correlation analysis results

"latest country entered was EU"

\begin{tabular}{lll}
\hline Variables & & \\
\hline & rh & P-Value \\
& & \\
Economic stability Host & 0.2 & 0.05 \\
Legal restrictions Host & 0.26 & 0.01 \\
Acceptability of the firm's products Host & 0.2 & 0.05 \\
Market potential Host & 0.28 & $<0.01$ \\
Stengths of prices and products & -0.2 & 0.05 \\
Extent of new external technology & 0.22 & 0.03 \\
Extent of R\&D & 0.21 & 0.04 \\
Knowledge of foreign markets & 0.28 & $<0.01$ \\
\hline
\end{tabular}

Table 6 Correlation analysis results

"Latest foreign market entry mode"

\begin{tabular}{lll}
\hline Variables & & \\
\hline & $\mathrm{Rh}$ & P-Value \\
& & \\
Firm's first entry mode & 0.28 & $<0.01$ \\
Competitor beginning to export & 0.2 & 0.05 \\
Government policy & 0.2 & 0.05 \\
EU membership of the UK & 0.2 & 0.05 \\
\hline
\end{tabular}




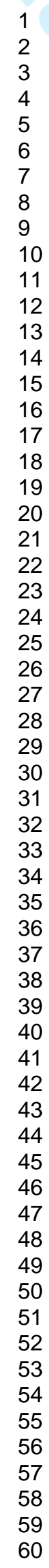




1
2
3
4
5
6
7
8
9
10
11
12
13
14
15
16
17
18
19
20
21
22
23
24
25
26
27
28
29
30
31
32
33
34
35
36
37
38
39
40
41
42
43
44
45
46
47
48
49
50
51
52
53
54
55
56
57
58
60

14

15

16

17

18

20

21

22

23

25

26

27

28

30

31

33

34

35

36

37

38

39

40

41

42

44

45

46

47

48

49

50

52

53

54

55

57

58

59

60

http://mc.manuscriptcentral.com/ijebr 


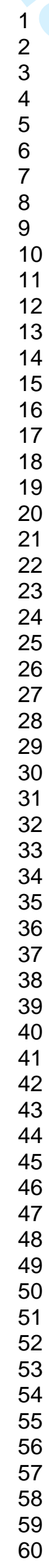


Figure 1 Theoretical framework

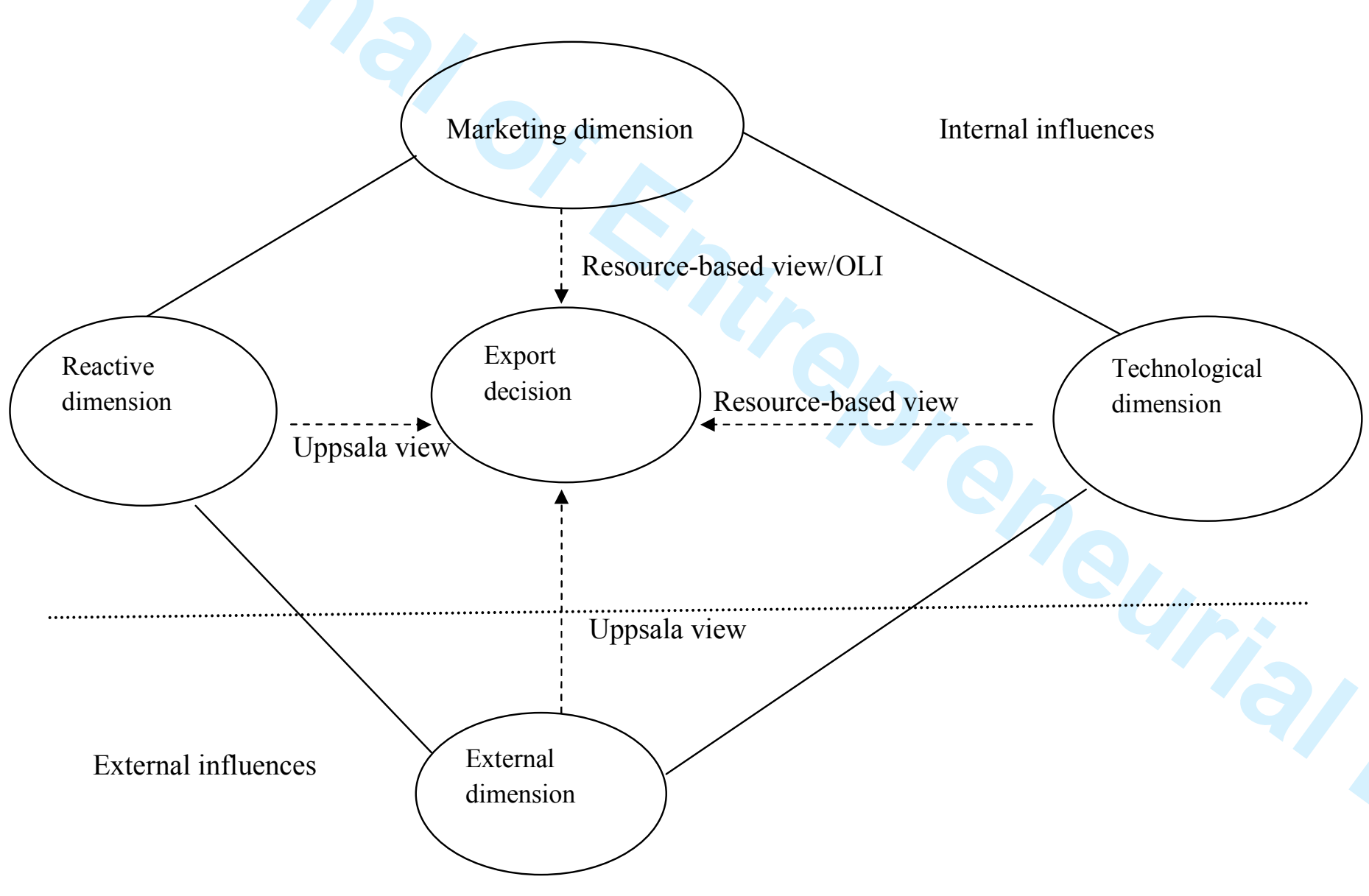

http://mc.manuscriptcentral.com/ijebr 
Figure 2 The associations tested by the hypotheses.
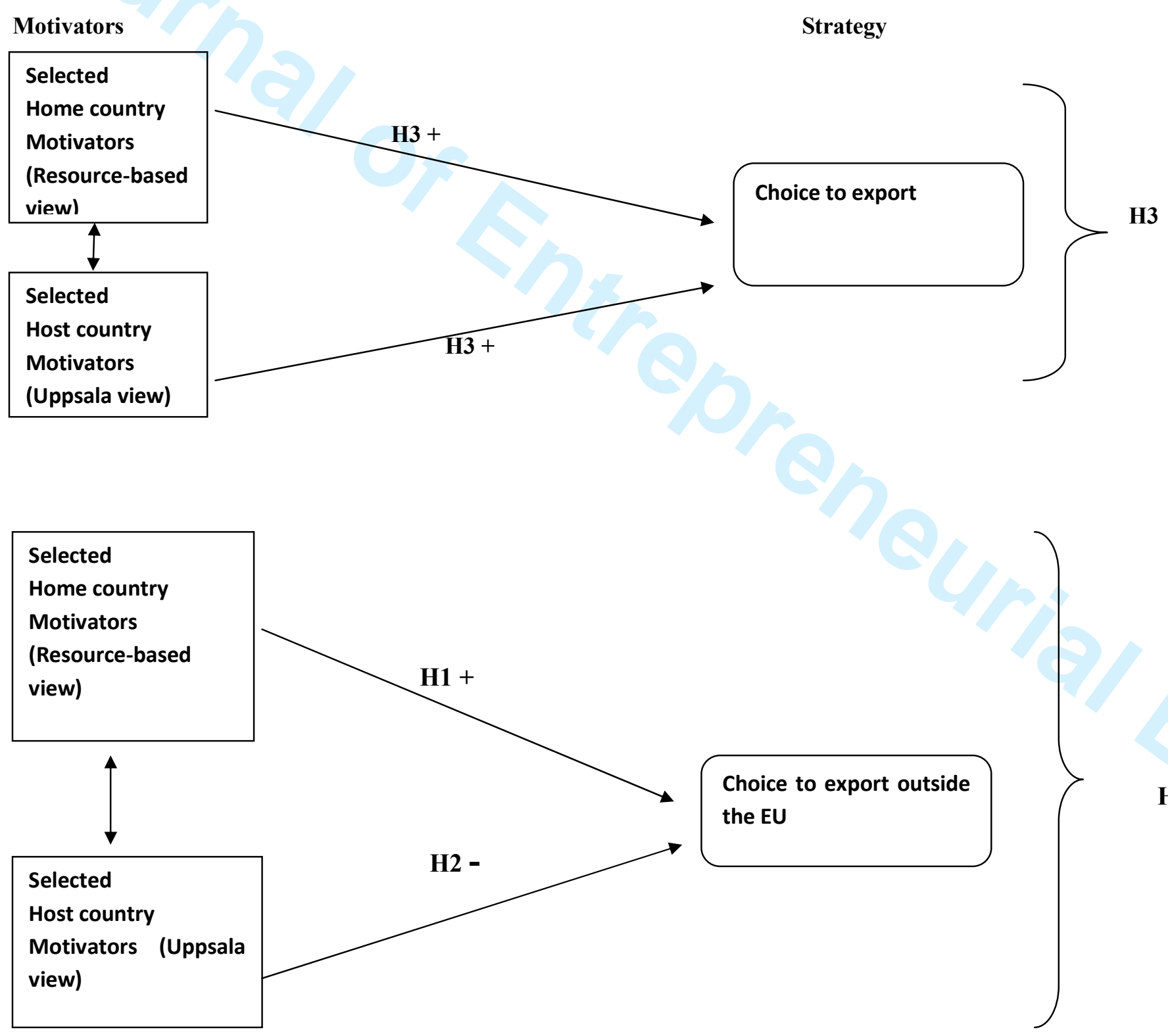

H1/ H2

http://mc.manuscriptcentral.com/ijebr 
Figure 3 Scatter plot

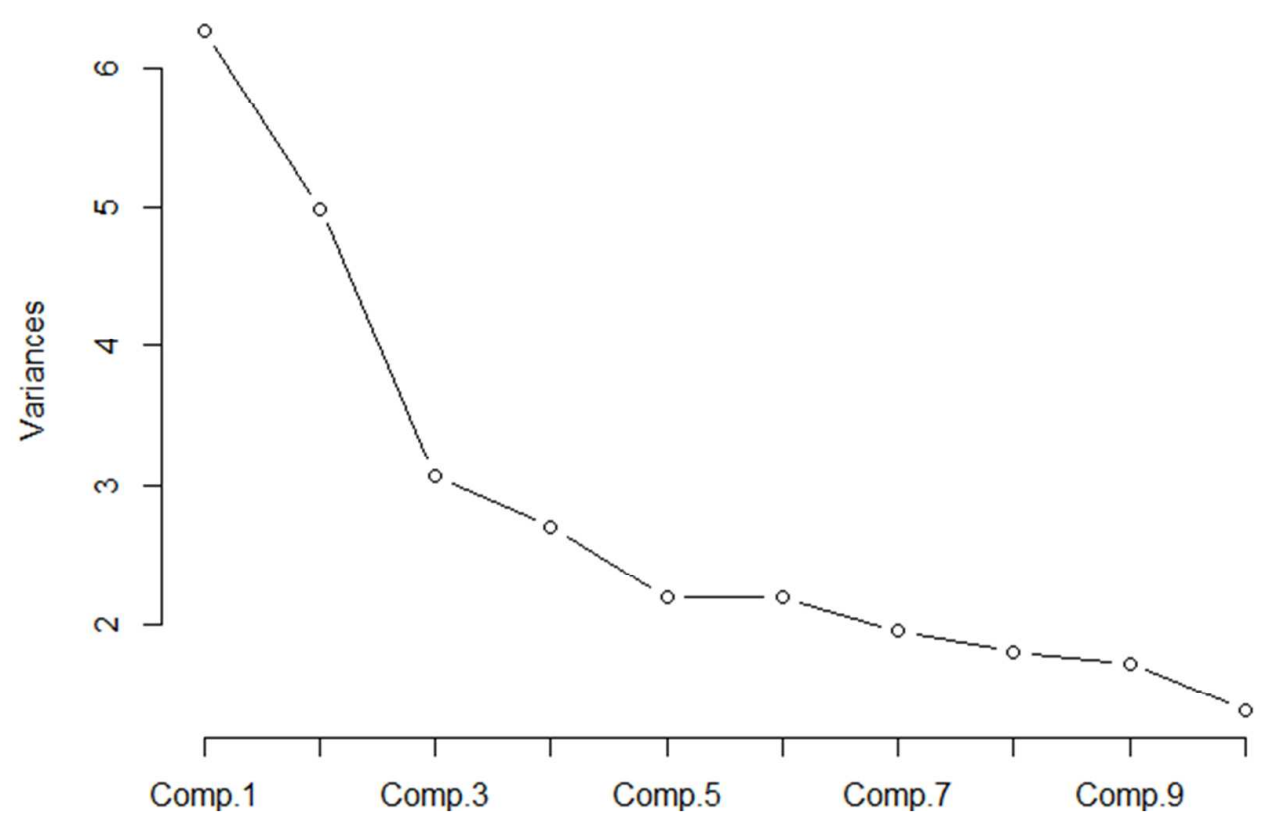

http://mc.manuscriptcentral.com/ijebr 